\title{
Predictions of the incidence of gastrointestinal cancers in the Świętokrzyskie region by the year 2025
}

\section{Prognozy zachorowalności na nowotwory złośliwe narząów trawiennych w województwie świętokrzyskim do 2025 roku}

\author{
Małgorzata Biskup ${ }^{1,2}$, Paweł Macek ${ }^{3,4}$, Halina Król1,5, Monika Nogajczyk³, Małgorzata Terek-Derszniak², \\ Tomasz Skowronek², Zdzisława Rugała6 ${ }^{6}$, Stanisław Góźdźn
}

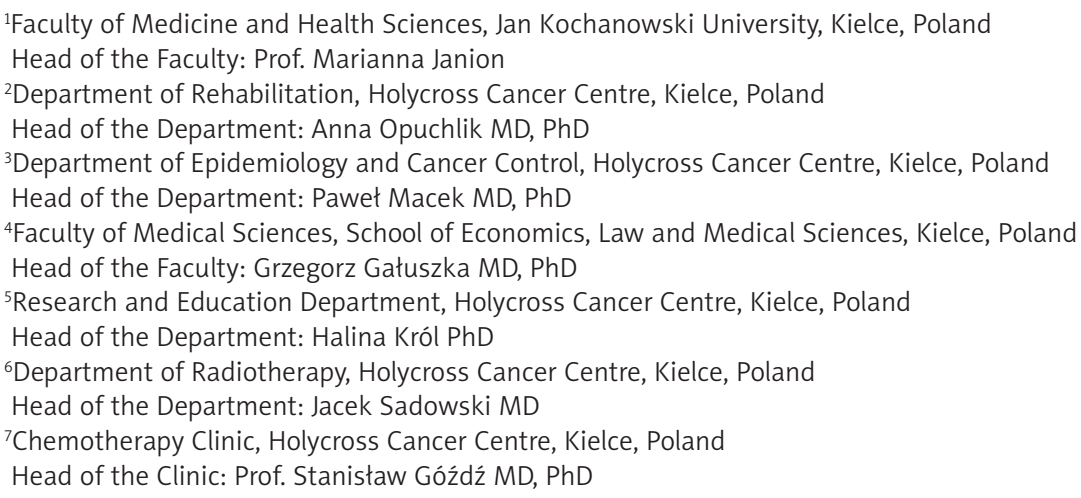

Key words: cancer, cancer incidence, Świętokrzyskie region.

Słowa kluczowe: nowotwory złośliwe, zachorowalność na nowotwory, województwo świętokrzyskie.

\begin{abstract}
Introduction: Malignant tumours are a growing health problem in Polish society. The authors have made an attempt to estimate the incidence of tumours of digestive organs in the future - among others, colorectal cancer, constituting $17.4 \%$ of cases in men and $10.0 \%$ among women. The above assessment is important for administrative reasons (allocation of resources, e.g. between prevention, diagnosis, treatment, social assistance) and scientific (evaluation of the effectiveness of interventions). Aim of the research: To forecast the incidence of selected gastrointestinal cancers in the Świętokrzyskie region by the year 2025.

Material and methods: The research material consisted of the data concerning 13,002 incidences of gastrointestinal cancers in the Świętokrzyskie region in the period from 1999 to 2014 produced by the National Cancer Registry. The Hakulinen and Dyba method developed by the Finnish Cancer Registry was used to estimate the expected morbidity and incidence rates in the period of 10 years.

Results: The rate of the expected morbidity and incidence rates in 2025 compared to 2014 is presented for stomach, colon, rectum, and liver cancers in men and women.

Conclusions: The predictions in terms of the incidence of cancers, including rectum and liver cancers in men as well as colon and rectum cancers in women, in the Świętokrzyskie region indicate an upward trend compared to the year 2014. A downward trend in morbidity refers to stomach and colon cancers in men as well as stomach and liver cancers in women.
\end{abstract}

\section{Streszczenie}

Wprowadzenie: Nowotwory złośliwe stanowią narastający problem zdrowotny polskiego społeczeństwa. Autorzy podjęli próbę oszacowania częstości występowania nowotworów narządów trawiennych w przyszłości, m.in. nowotworu jelita grubego, który stanowi 17,4\% zachorowań u mężczyzn oraz 10,0\% u kobiet. Powyższa ocena ma istotne znaczenie ze względów administracyjnych (rozdysponowanie zasobów, np. między profilaktykę, diagnostykę, leczenie, pomoc społeczną) oraz ze względów naukowych (ocena skuteczności interwencji).

Cel pracy: Prognoza zachorowalności na wybrane nowotwory złośliwe narządów trawiennych w województwie świętokrzyskim do $2025 \mathrm{r}$. 
Materiał i metody: Materiał badawczy stanowiły dane o 13002 zachorowaniach na nowotwory złośliwe narządów trawiennych w województwie świętokrzyskim w latach 1999-2014, które pochodziły z Krajowego Rejestru Nowotworów. Do oszacowania oczekiwanej liczby zachorowań i współczynników zachorowalności w ciągu 10 lat użyto metody Hakulinena i Dyby opracowanej w Fińskim Rejestrze Nowotworów.

Wyniki: Wyniki oczekiwanej zachorowalności oraz liczby zachorowań w 2025 r. w stosunku do 2014 r. przedstawiono dla nowotworów złośliwych żołądka, jelita grubego, odbytu i wątroby u mężczyzn i kobiet.

Wnioski: Prognozy zachorowalności na nowotwory złośliwe w województwie świętokrzyskim wskazują tendencję wzrostową w porównaniu z 2014 r. w przypadku nowotworów odbytu i wątroby u mężczyzn oraz nowotworów jelita grubego i odbytu u kobiet. Tendencja spadkowa liczby zachorowań dotyczy nowotworów złośliwych żołądka i jelita grubego u mężczyzn, a u kobiet nowotworów złośliwych żołądka i wątroby.

\section{Introduction}

Malignant tumours are a growing health, social, and economic problem in Polish society. Their scale is determined by the number of new cases $(163,300)$, deaths $(100,600)$, and more than 999 thousand people living with cancer at the beginning of the second decade of the $20^{\text {th }}$ century. It is estimated that in 2015 more than 425 people for every 100 thousand in the Polish population were diagnosed with cancer, and approximated 2470 have lived with diagnosed cancer over the last 15 years [1].

The most common malignant tumours registered in 2015 in men included lung cancer (17.7\%), prostate cancer $(17.4 \%)$, and colon cancer $(7.0 \%)$ followed by bladder cancer $(6.5 \%)$, rectum cancer $(4.4 \%)$, and stomach cancer $(4.3 \%)$. In women the most common cancers diagnosed in 2015 were breast cancer (22.2\%), lung cancer (9.2\%), endometrial cancer (7.6\%), colon cancer (6.2\%), ovarian cancer $(4.6 \%)$, and cervical cancer $(3.3 \%)$ [1]

In the last half century (1965-2014) the incidence of cancer and the number of deaths have risen dramatically: in men the incidence increased by more than 62 thousand whereas in women by more than 59 thousand, which means that the total incidence rate has quadrupled [2].

Our study concerns the problem of the incidence of cancers defined according to the ICD classification as gastrointestinal cancers, which include malignant tumours of the stomach, the colon, the rectum, and the liver.

Despite the ongoing decline in the incidence and mortality, stomach cancer remains the fourth most common malignant tumour and the second cause of death from cancer in the world. The incidence is particularly high in the eastern part of Asia (more than 40/105), Eastern Europe (approximately 25/105), Central America $\left(30 / 10^{5}\right)$, and South America $\left(20 / 10^{5}\right)$. The share of stomach cancer in the cancer incidence rate in Poland has decreased over the last four decades almost three times. At present, stomach cancer in men constitutes approximately $5 \%$ of all cases whereas in women only $3 \%$ [3].

The incidence of stomach cancer in 2015 amounted to 3523 in men and 1940 in women [1]. Most cases of stomach cancer occur in patients after the age of 50 years (93\% of cases in men and $91 \%$ of cases in women) with about $3 / 4$ of cases in both sexes occurring in the population of the elderly (after the age of 65 years).
The risk of developing stomach cancer increases with age, and in men it is approximately two to three times higher than in women. In men, the incidence reaches its peak in the ninth decade of life (approximately 125/10 ). In women the highest incidence is observed in the eighth and ninth decades $\left(40-50 / 10^{5}\right)$ [3].

Colon cancer and rectum cancer are the third most common cancers in the world in men $(660,000$ cases, $10 \%)$ and the second most common in women $(570,000$ cases, $9 \%$ ). Almost $60 \%$ of cases occur in developed countries. The differences in morbidity between populations are more than 10-fold: the highest incidence is recorded in Australia, New Zealand, and Western Europe and the lowest in Africa and South-Central Asia. The incidence is twice as frequent in men than in women [3].

In Poland, the colon cancer rate in men reaches about $17.4 \%$ and $10.0 \%$ in women. The incidence of colon cancer in 2015 reached 10,271 cases (5742 colon 856 rectosigmoid colon, 3571 rectum, 102 anus) in men and 8186 in women (5073 colon, 640 rectosigmoid colon, 2245 rectum, 228 anus) [1].

Since 1980 there has been an almost fourfold increase in the number of cases in men and a threefold increase in women. The majority of colon cancers occur in patients after the age of 50 years $(94 \%$ cases in men and $91 \%$ cases in women) with about $75 \%$ of cases in both sexes occurring in the population of the elderly (after the age of 60 years). The risk of developing colon cancer increases with age, and in men it is approximately one and a half to two times higher than in women. In men, the incidence reaches its peak at the turn of the eighth and ninth decades decade of life (approximately $300 / 10^{5}$ ). In women the highest incidence is observed in the eighth and ninth decades $\left(150 / 10^{5}\right)$. The incidence of colon cancer in men at the beginning of the twenty-first century was characterised by rapid growth, which in the last decade has been considerably weakened. The rapid growth of the incidence in the female population continued until the mid-90s of the twentieth century, and since then the growth rate has slowed down [1].

Liver cancer accounts for $7 \%$ of disease in the world, with approximately $80 \%$ of cases occurring in economically underdeveloped countries. Liver cancer is three times more common in men than in women. Every year, there are about 750,000 diagnosed cases. The incidence is particularly high in East and Southe- 
ast Asia $\left(40-50 / 10^{5}\right)$. A lower rate of incidence is observed in developed countries, with the exception of Southern Europe (France, Spain, Italy, Greece, Romania). The incidence of deaths from liver cancer is similar to its morbidity due to the poor prognosis of this type of cancer. In Poland, liver cancer in men accounts for approximately $1.2 \%$ of incidence, whereas in women it is $0.8 \%$ [3]. The incidence of liver cancer in 2015 amounted to 876 in men and 642 in women [1].

Most cases of liver cancer occur after the age of 55 years $(82 \%$ of cases in men and $88 \%$ of cases in women). The risk of cancer increases with age, reaching a peak in the ninth decade of life in both sexes ( $>25 / 10$ in men and about 17/10 in women) [3].

Cancer control, which includes more than 100 diseases, requires the application of different strategies due to a wide range of diagnostic tests, and varied aetiology and treatment [4]. In this case, primary and secondary prevention is as important as the treatment. The data provided by the World Health Organisation indicate that through prevention one third of cancers could be prevented, one third could be cured, and in the case of the remaining one third of cases the quality of live could be improved [5, 6].

The observed increase in morbidity and mortality due to malignant tumours in the last half century results from the aging of the Polish population and frequently from exposure to carcinogens, which is primarily related to the lifestyle of the Polish population [4].
The estimation of the incidence of cancer in a given population in the future is interesting not only from an administrative point of view but also from a scientific one. Administrative considerations require greater precision in obtaining data that allow the best allocation of resources to, for instance, prevention (measures to reduce smoking tobacco), diagnosis (screening tests), treatment, rehabilitation, social assistance, or hospice care. Predicting the risk of cancer is also interesting due to scientific reasons. The analysis of historical trends as well as prediction, even in the short term, makes it possible to assess the changes in the exposure to risk factors (as exemplified by lung cancer in Poland and other tobacco-related cancers, including larynx cancer or bladder cancer) and to evaluate the effectiveness of interventions. Similarly, the effectiveness of screening programs can be evaluated (a comparison of a short-term prediction of mortality) [7].

\section{Aim of the research}

The main objective of the study was to make predictions as to the incidence of selected gastrointestinal cancers in the Świętokrzyskie region by the year 2025.

\section{Material and methods}

The analysis included information of the incidence of gastrointestinal cancers according to the topogra-

Table 1. Gastrointestinal cancer incidence by gender in the Świętokrzyskie region, 1999-2014

\begin{tabular}{|lccccccccc|}
\hline Year & \multicolumn{2}{c}{ Stomach } & \multicolumn{2}{c}{ Colon } & \multicolumn{2}{c}{ Rectum } & \multicolumn{2}{c|}{ Liver } \\
\cline { 2 - 10 } & Men & Women & Men & Women & Men & Women & Men & Women \\
2000 & 151 & 96 & 127 & 138 & 86 & 91 & 14 & 17 \\
2001 & 154 & 88 & 144 & 117 & 130 & 112 & 14 & 10 \\
2002 & 165 & 77 & 137 & 146 & 123 & 81 & 29 & 24 \\
2003 & 165 & 101 & 153 & 145 & 132 & 84 & 33 & 29 \\
2004 & 182 & 93 & 145 & 116 & 110 & 96 & 24 & 20 \\
2005 & 159 & 81 & 161 & 142 & 122 & 83 & 26 & 27 \\
2006 & 134 & 67 & 153 & 160 & 134 & 99 & 23 & 11 \\
2007 & 123 & 71 & 151 & 158 & 103 & 85 & 19 & 23 \\
2008 & 142 & 65 & 182 & 154 & 130 & 96 & 13 & 12 \\
2009 & 131 & 65 & 190 & 157 & 126 & 95 & 17 & 14 \\
2010 & 131 & 79 & 208 & 165 & 131 & 89 & 24 & 34 \\
2011 & 139 & 78 & 218 & 170 & 153 & 89 & 38 & 14 \\
2012 & 134 & 83 & 222 & 185 & 139 & 111 & 16 & 19 \\
2013 & 122 & 64 & 211 & 176 & 146 & 79 & 26 & 21 \\
2014 & 138 & 63 & 216 & 169 & 127 & 78 & 23 & 16 \\
$1999-2014$ & 130 & 61 & 235 & 172 & 131 & 79 & 30 & 17 \\
\hline
\end{tabular}


phic codes of the International Statistical Classification of Diseases and Related Health Problems ICD-10: stomach cancer (C16), colon and rectosigmoid colon cancer C18-C19, rectum cancer, anus cancer, and anal canal cancer C20-C21, as well as liver cancer C22.

The data concerning 13,002 cases (7545 in men and 5475 in women) of gastrointestinal cancers as well as the population of the Świętokrzyskie region in each year of the analysis, according to the place of residence as at June 30 (in total in 5-year age groups starting from the age of 15 until the age of $85+$ years by gender) in the Świętokrzyskie region in the years 1999-2014 were collected from the website of the National Cancer Registry (http://onkologia.org.pl) (Table 1). The data concerning the projected population until the year 2025 were collected from the website of the Central Statistical Office (http://stat.gov.pl).

In the National Cancer Registry, the term "morbidity" is usually replaced by the term "registered morbidity" in order to emphasise that the reported data on incidence is still burdened with some non-registrations, which vary both with time and within the country. As the simplest measure of the completeness of the registration of malignant tumours in individual voivodships, the National Register of Cancers uses the death/disease rate, which is the quotient of the number of deaths due to malignant neoplasms and the number of newly registered malignant neoplasms in total at the same time.

\section{Data verification}

Data on malignant tumours published by the $\mathrm{Na}$ tional Cancer Registry are collected and verified in Regional Cancer Registry Offices. The verification stages concern the identification of all cases of malignant neoplasms in situ (published separately) as well as cases of benign tumours of unverified character (benign or malignant tumour), metastatic, and unverified lesions (metastasis or primary tumour). The verification also applies to all cases diagnosed only on the basis of the death certificate and sectional examination (DCO), of unknown gender, inconsistency of location and morphology, age and location, age and morphology, and age, location, and morphology.

\section{Statistical analysis}

The Hakulinen and Dyby methods elaborated in the Finnish Cancer Registry were used to estimate the expected number of cases and incidence rates in the 5- and 10-year horizon [8]. In the log-linear prediction model used, it was assumed that undesirable events occurring in time (illnesses) derive from the Poisson distribution. The dependent variable was the number of malignant tumours according to location, sex, 5-year age groups and calendar year, and the continuous predictor was a calendar year of occurrence of the disease. Natural logarithm from the population number in 5-year age groups, by sex, in a given calendar year, was used as the shift variable. Modelling of the expected number of cases was based on the prognosis of the number of cases of selected malignancies in 5-year age groups by sex and tumour location in the Świętokrzyskie Voivodeship in the years 1999-2014. The expected morbidity in the 5-year age groups was estimated as the exponent of the sum of the directional $\beta$ coefficients for the free expression and 5-year age group multiplied by a calendar year. The obtained value multiplied by the population in the 5 -year age group allowed us to obtain the expected number of cases in this age group. The calendar year was counted from zero. By substituting values greater than 15 for the calendar year and using population size forecasts by 2025 published by the Central Statistical Office, the expected values of the incidence rate and the number of cases were obtained. Based on the expected number of cases, the expected values of standardised incidence rates were estimated. For both the expected number of cases and expected values of incidence rates, the 95\% confidence intervals were given. Statistical analyses together with a graphical interpretation were prepared using R 3.4.2 for Windows.

\section{Results}

In 2025, as compared to 2014, an increase in rectum cancer (7.7\%) and liver cancer $(24.7 \%)$ in men as well as colon cancer $(20.8 \%)$ and rectum cancer (3.3\%) in women is expected. A decrease in the incidence of stomach cancer (25.5\% in men and $14.1 \%$ in women) as well as colon cancer in men (44.8\%) is expected. In 2025 as compared to 2014 the predicted incidence of liver cancer in women will not change significantly (0.2\%).

Among the analysed gastrointestinal cancers the highest expected rate of incidence in both men and women will involve colon cancer (men $-37.6 / 10^{5}$ person-years; women $-17.4 / 10^{5}$ person years) and rectum cancer (men - 15.9/10 $0^{5}$ person-years; women 6.6/10 person-years). The lowest incidence rate in both sexes is expected in the case of stomach cancer (men $11.2 / 10^{5}$ person-years; women $-4.1 / 10^{5}$ person-years) and liver cancer (men $-4.0 / 10^{5}$ person-years; women $-1.5 / 10^{5}$ person-years) (Figure 1 ).

Regardless of the direction and dynamics of changes in the case of malignant tumours of the stomach, the colon and the rectum in both sexes, and the liver in women, the highest predicted incidence will affect the elderly over the age of 65 years. Only in the case of the liver cancer will the highest predicted incidence affect middle-aged men (50-54 years of age) (Table 2).

According to the forecast, the number of cases of stomach cancer in men in 2025 will amount to 118 cases (95\% CI: 87-149) and 53 cases in women (95\% CI: 33-73). The expected decline in the number of ca- 


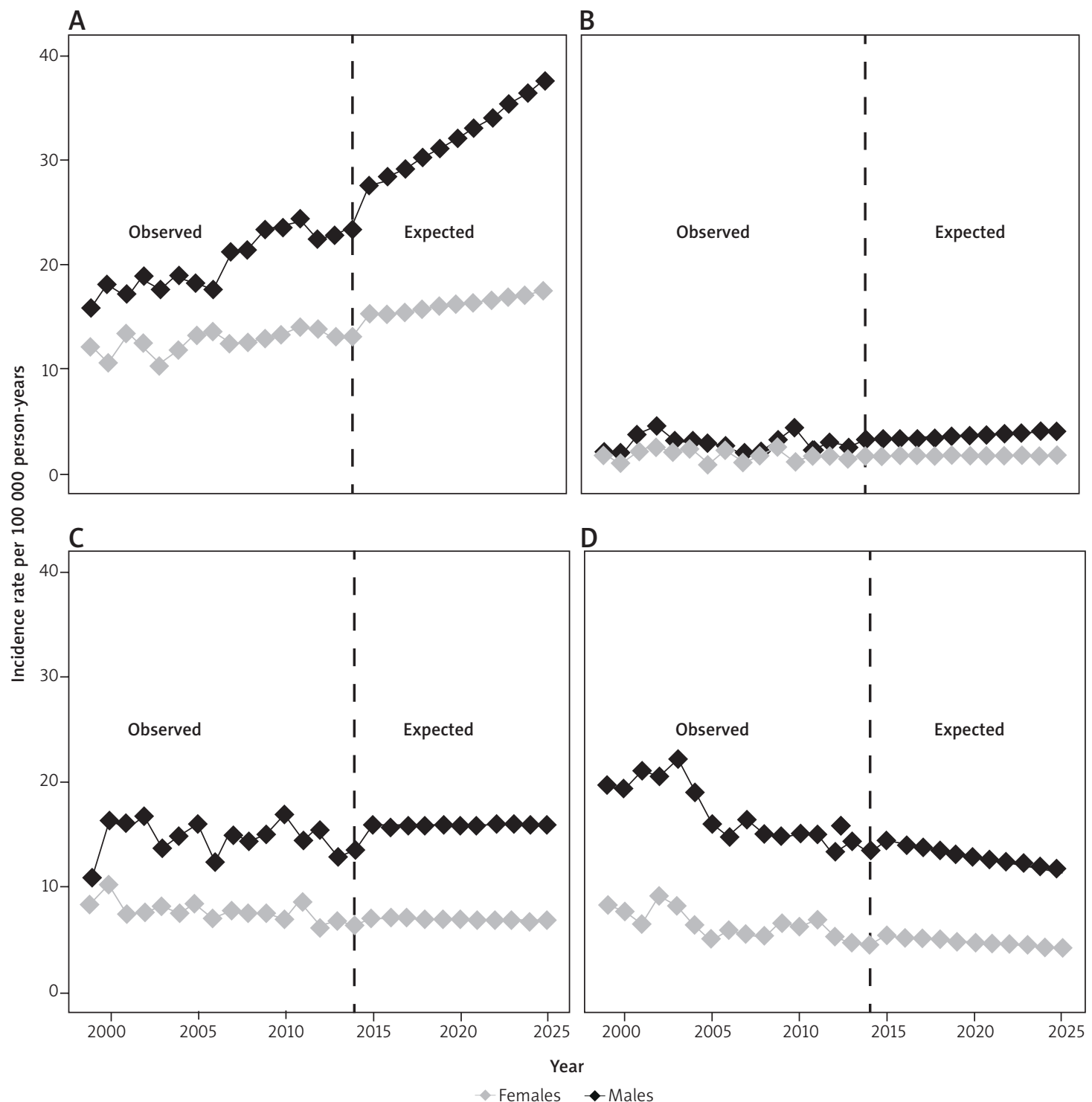

Figure 1. Predictions in terms of the incidence of gastrointestinal cancers (colon (A), liver (B), rectum (C), stomach (D)) in the Świętokrzyskie region by the year 2025 by gender

ses compared to 2014 will amount to $9.1 \%$ in men and $13.2 \%$ women. The estimated number of cases of colon cancer in men in 2025 will reach 424 cases (95\% CI: 345-502) and 250 cases (95\% CI: 196-303) in women. The expected increase in the number of cases compared to 2014 will amount to $80.2 \%$ in men and $45.3 \%$ in women. The predicted incidence rate of rectum cancer indicates an increase in both men (33.4\%) and women (5.9\%). The expected number of cases in men will reach 175 (95\% CI: 133-217) and 84 (95\% CI: 57-110) in women. According to the forecast, the number of cases of liver cancer in males will reach 39 (95\% CI: 14-64) and 20 (95\% CI: 6-33) in women. The expected increase in the number of cases compared to 2014 will amount to $29.0 \%$ in men and $15.6 \%$ among women (Figure 2).

\section{Discussion}

According to forecasts, the number of cancers in Europe will grow from 3.4 million in 2008 to 4.1 million in 2030, assuming the immutability of the current coefficients, and to 5.5 million cases assuming a $1 \%$ annual growth rate of coefficients [4]. This means that 0.7 million cases in Europe will be exclusively the result of the aging population [7].

Our results covering the Świętokrzyskie region indicate the expected increase in incidence of rectum and colon cancers in men as compared to 2014. The decrease in incidence in men will apply to cancers of the stomach and the colon.

On the other hand, in women the expected increase in morbidity as compared to 2014 will affect colon 
Table 2. Gastrointestinal cancer incidence in total and in 5-year age groups in 2025, Świętokrzyskie region

\begin{tabular}{|c|c|c|c|c|c|c|c|c|}
\hline \multirow{2}{*}{$\begin{array}{l}\text { Age } \\
\text { group }\end{array}$} & \multicolumn{2}{|c|}{ Stomach } & \multicolumn{2}{|c|}{ Colon } & \multicolumn{2}{|c|}{ Rectum } & \multicolumn{2}{|c|}{ Liver } \\
\hline & Males & Females & Males & Females & Males & Females & Males & Females \\
\hline & \multicolumn{8}{|c|}{ Rate per $10^{5}$ person-years $(95 \% \mathrm{Cl})$} \\
\hline \multirow[t]{2}{*}{$15-44$} & 0.8 & 0.5 & 1.2 & 1.0 & 0.4 & 0.4 & 0.4 & 0.0 \\
\hline & $(0.0-1.9)$ & $(0.0-1.4)$ & $(0.0-2.7)$ & $(0.0-2.4)$ & $(0.0-1.1)$ & $(0.0-1.2)$ & $(0.0-1.4)$ & $(0.0-0.3)$ \\
\hline \multirow[t]{2}{*}{$45-49$} & 1.2 & 0.4 & 0.8 & 0.6 & 0.6 & 0.3 & 0.6 & 0.2 \\
\hline & $(0.0-2.5)$ & $(0.0-1.0)$ & $(0.0-1.9)$ & $(0.0-1.4)$ & $(0.0-1.5)$ & $(0.0-0.8)$ & $(0.0-2.5)$ & $(0.0-0.9)$ \\
\hline \multirow[t]{2}{*}{$50-54$} & 0.5 & 0.5 & 1.5 & 1.9 & 0.9 & 1.3 & 0.0 & 0.2 \\
\hline & $(0.0-1.1)$ & $(0.0-1.1)$ & $(0.3-2.6)$ & $(0.3-3.5)$ & $(0.0-1.8)$ & $(0.1-2.6)$ & $(0.0-0.1)$ & $(0.0-0.8)$ \\
\hline \multirow[t]{2}{*}{$55-59$} & 0.5 & 0.2 & 2.4 & 1.1 & 2.2 & 1.1 & 0.7 & 0.1 \\
\hline & $(0.0-1.2)$ & $(0.0-0.6)$ & $(0.8-4.1)$ & $(0.1-2.1)$ & $(0.6-3.8)$ & $(0.0-2.1)$ & $(0.0-1.7)$ & $(0.0-0.5)$ \\
\hline \multirow[t]{2}{*}{$60-64$} & 1.5 & 0.2 & 3.1 & 2.5 & 2.4 & 0.4 & 0.3 & 0.1 \\
\hline & $(0.4-2.5)$ & $(0.0-0.6)$ & $(1.4-4.8)$ & $(1.0-4.1)$ & $(1.0-3.9)$ & $(0.0-1.0)$ & $(0.0-0.7)$ & $(0.0-0.4)$ \\
\hline \multirow[t]{2}{*}{$65-69$} & 1.3 & 1.0 & 7.6 & 2.5 & 2.0 & 0.7 & 0.6 & 0.2 \\
\hline & $(0.4-2.1)$ & $(0.2-1.9)$ & $(4.6-10.6)$ & $(1.1-3.9)$ & $(0.8-3.2)$ & $(0.1-1.4)$ & $(0.0-1.3)$ & $(0.0-0.6)$ \\
\hline \multirow[t]{2}{*}{$70-74$} & 1.6 & 0.3 & 5.0 & 3.3 & 2.5 & 0.5 & 0.3 & 0.2 \\
\hline & $(0.7-2.5)$ & $(0.0-0.6)$ & $(2.9-7.1)$ & $(1.8-4.8)$ & $(1.1-3.9)$ & $(0.1-1.0)$ & $(0.0-0.8)$ & $(0.0-0.4)$ \\
\hline \multirow[t]{2}{*}{$75-79$} & 1.7 & 0.6 & 7.2 & 2.7 & 3.1 & 1.2 & 0.4 & 0.2 \\
\hline & $(0.7-2.8)$ & $(0.1-1.1)$ & $(4.1-10.2)$ & $(1.4-4.0)$ & $(1.3-4.9)$ & $(0.3-2.0)$ & $(0.0-1.0)$ & $(0.0-0.5)$ \\
\hline \multirow[t]{2}{*}{$80-84$} & 0.5 & 0.3 & 6.8 & 0.7 & 1.0 & 0.2 & 0.2 & 0.1 \\
\hline & $(0.0-1.1)$ & $(0.0-0.6)$ & $(3.2-10.4)$ & $(0.2-1.2)$ & $(0.1-1.9)$ & $(0.0-0.5)$ & $(0.0-0.6)$ & $(0.0-0.3)$ \\
\hline \multirow[t]{2}{*}{$85+$} & 1.5 & 0.2 & 1.9 & 0.9 & 0.7 & 0.4 & 0.5 & 0.1 \\
\hline & $(0.2-2.8)$ & $(0.0-0.4)$ & $(0.4-3.5)$ & $(0.3-1.5)$ & $(0.0-1.5)$ & $(0.0-0.8)$ & $(0.0-1.5)$ & $(0.0-0.2)$ \\
\hline \multirow[t]{2}{*}{$15-85+$} & 11.2 & 4.1 & 37.6 & 17.4 & 15.9 & 6.6 & 4.0 & 1.5 \\
\hline & $(8.1-14.2)$ & $(2.3-5.9)$ & $(30.6-44.5)$ & $(13.5-21.2)$ & (12.1-19.7) & $(4.3-8.9)$ & $(1.2-6.9)$ & $(0.3-2.7)$ \\
\hline
\end{tabular}

and rectum cancers. The projected decline in the incidence in women will affect stomach and liver cancers.

The expected increase in the number of cases in men will affect colon, rectum, and liver cancers. The decrease in the number of cases in men will affect stomach cancer.

In women the expected increase in the number of cases will affect malignant tumours of the colon and the rectum whereas the decrease will concern the stomach and the liver.

The highest expected incidence of stomach cancer will occur in the 75-79 age group in men and 65-69 in women, similarly to colon cancer (men 65-69 age group, women 70-74 age group). The projected lowest incidence in women will include stomach and rectum cancers, which will occur in the $80+$ age group. In turn, colon and liver cancers will concern the 0-44 age group and the 45-49 age group (the colon). In men the lowest expected morbidity will refer to stomach, colon, and liver cancers in 50-54 age group (liver and stomach cancers) and the 45-49 age group (colon cancer).

Stomach and lung cancers are the most important locations, which in the past, since the mid-twentieth century, determined the risk of cancer in Poland. The picture of time trends of the above locations in both sexes has had a decisive impact on the epidemiology of cancer in Poland. According to the literature, in the case of malignant tumours of the stomach both the morbidity and mortality have been continuously decreasing since the beginning of the $20^{\text {th }}$ century $[8,9]$.

The above forecasts for the Świętokrzyskie region confirm further declines in morbidity.

The epidemiological picture of stomach cancer results from poorly identified risk factors and protective factors. During the twentieth century, the epidemiological picture pointed to a decrease in the morbidity and mortality from stomach cancer. The reason for this phenomenon was a "by-product" of our civilisation development rather than deliberate intentions. The above phenomenon was descri- 

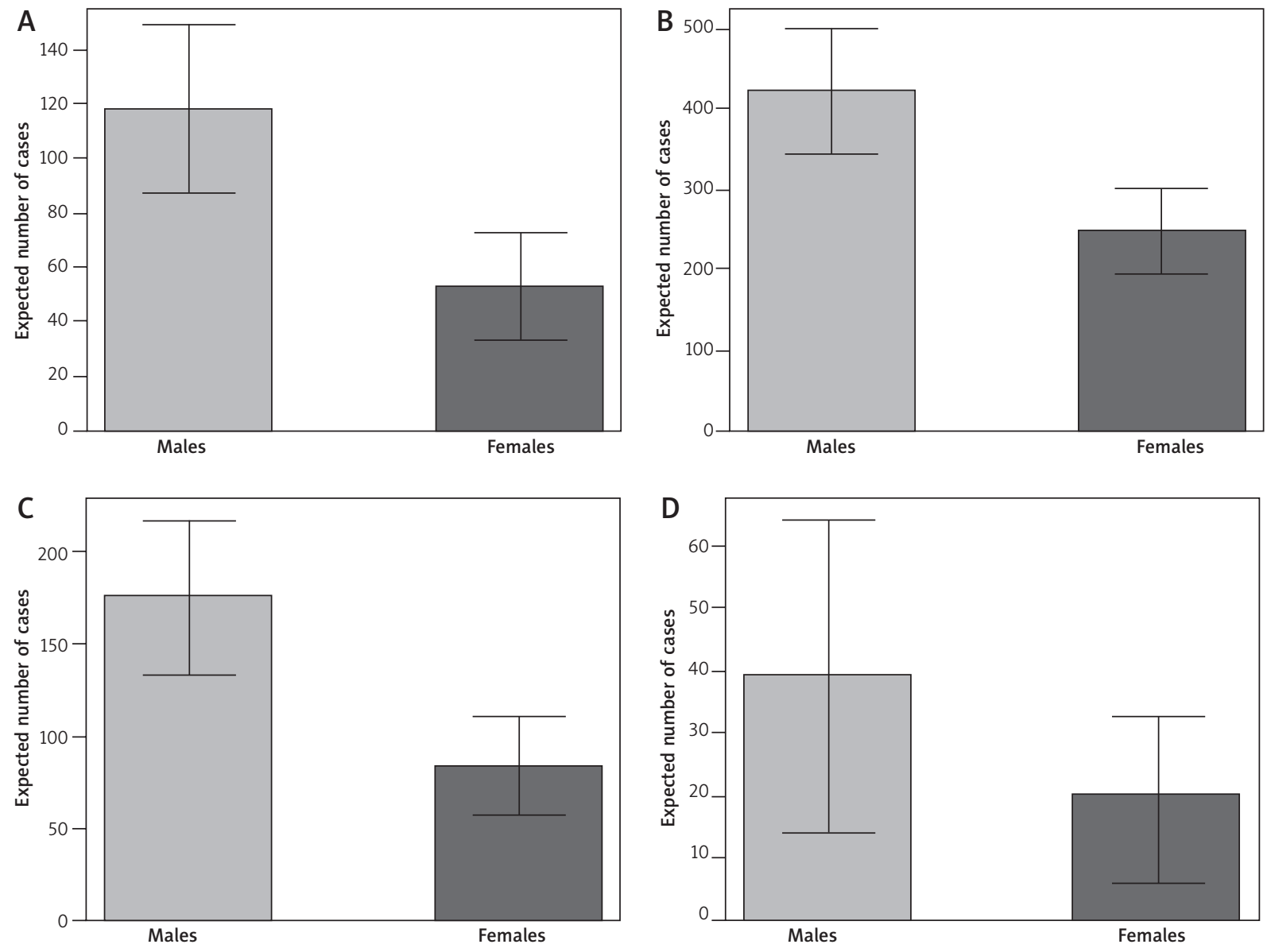

Figure 2. Predictions in terms of the incidence of gastrointestinal cancers (stomach (A), colon (B), rectum (C), liver (D)) in the Świętokrzyskie region by the year 2025 by gender

bed in Ernest Wynder's work entitled "The Decline in Gastric Cancer: Epidemiology of an Unplanned Triumph" [10-12]. This example shows that it is not entirely correct to say that cancer diseases are civilisation diseases. The development of civilisation may also be a factor reducing the risk of these diseases, and problems with cancer have long been known. Autopsy reports of the Jagiellonian University from the nineteenth and early twentieth centuries confirm the occurrence of gastric cancer as historically the most frequent malignant tumour in the Polish population. Until 1970, it remained the most common cancer in both sexes. Since then, the risk of getting stomach cancer has fallen dramatically. Unfortunately, despite such positive changes, the frequency of cancer of the stomach is constantly 4-5 times higher in Poland and in other Eastern European countries compared to the Scandinavian countries. Particularly distressing is the lack of perspectives for the treatment of this type of cancer although its incidence in the coming decades is likely to decrease [10-12]. Research conducted for decades seem to indicate an important role of Helico- bacter pylori infection and its control in the aetiology of stomach cancer. It is believed that by increasing the consumption of fruit and vegetables all year round, thanks to the storage of food at sufficiently low temperatures, the above rates will drop [10].

In the case of gastrointestinal cancers, diet plays a considerable role. Research has tied red meat with the risk of cancer because it contains polyunsaturated fatty acids, which are dangerous for health. Its high consumption causes the increase in the incidence of colon cancer. Regular and frequent consumption of fruit and vegetables, which may prevent certain types of cancer, such as stomach or colon cancer, should be promoted. The daily intake of fruit and vegetables should equal five portions. Regular consumption of fruit may reduce the risk of cancer by $20 \%$. Fibre, especially cellulose and other dietary fibres contained in cereal grains and cereal products, are also very important. A major source of fibre are the already-mentioned fruit and vegetables. It mainly protects against the risk of colon cancer and breast cancer but it also has a protective effect against cardiovascular diseases 
and type 2 diabetes Abnormal body weight may increase the risk of, among others, colon cancer and breast cancer [13].

It is therefore important to maintain normal body weight. Lack of physical activity is another major problem in the fight against cancer. Regular exercise can significantly reduce the incidence of cancer of the largest part of the large intestine, the colon [14].

In our study we demonstrated a predicted increase in the incidence of liver cancer in men and a decrease in women. This is an insidious disease, in most cases being the result of metastasis from other locations, tumours often arise in cirrhotic liver in individuals suffering from chronic viral hepatitis B and C, and alcohol abuse may contribute to the development of the disease. The probable cause of the decline in incidence among women is perhaps the improvement of lifestyle, which unfortunately is not confirmed by scientific studies, so the topic requires continuation on broader levels.

The prediction of health effects is both a necessary and flawed tool. Forecasting morbidity, and especially the number of cases, is crucial for the development of state health strategies and predicting future costs to society. Both direct costs (treatment) as well as indirect ones, resulting from the loss of social roles by people who are ill, should be taken into account. Predicting the effects concerning health, however, is extremely difficult, because not all determining factors are known (or can be measured) [15].

In Poland, it is not only the level of exposure to risk factors but also the delay in the implementation of prevention programs, in comparison with other countries, that is causing an increasing number of cases of, and deaths from, cancer. Population screening programs could detect the early stage of many cases of colon cancer. The problem, however, also relates to the low public awareness of the need for such tests, and to limited participation of persons in programs designed for them. Another aspect that affects the formation of tumours is the aging of the population. This creates a challenge for the health system [16].

The presented assessment of the incidence of malignant neoplasms of the digestive organs should be a valuable source of information for patients and physicians, but also for politicians who have a direct influence on the shaping of both health care policies and systems. It seems necessary to educate society in the prevention of cancer, resulting in an increase in public awareness and an increasing number of tests. The effect of the above will be increased detection of diseases in non-advanced stages, which will also translate into costs related to medical care.

\section{Conclusions}

Predictions concerning cancer incidence in the Świętokrzyskie region, as compared to 2014, indicate an upward trend in the case of rectum cancer, liver cancer in men, and colorectal cancer in women. A downward trend in cancer incidence refers to malignant tumours of the stomach and the colon in men and malignant tumours of the stomach and the liver in women.

Forecasts concerning the number of cancer cases in the Świętokrzyskie region, as compared to 2014, indicate an upward trend in the case of cancers of the colon, the rectum, and the liver in men and cancers of the colon and the rectum in women. A downward trend in cancer incidence refers to malignant tumours of the stomach in men and gastric cancers in women.

Forecasts concerning the highest incidence of cancer of the stomach, the colon, the rectum, and the liver occur in the fifth, sixth, and seventh decades of life for both men and women. The lowest incidence of cancer occurs mostly in the $80+$ age group (gastric and colorectal cancers in women) or the 44 age group (anal cancers in men).

\section{Conflict of interest}

The authors declare no conflict of interest.

\section{References}

1. Didkowska J, Wojciechowska U, Olasek P. Nowotwory złośliwe w Polsce w 2015 roku. Ministerstwo Zdrowia, Warszawa 2017.

2. Wojciechowska U, Olasek P, Czauderna K, Didkowska J. Nowotwory złośliwe w Polsce w 2014 roku. Ministerstwo Zdrowia, Warszawa 2016.

3. www.onkologia.org.pl

4. Zatoński W, Sulkowska U, Przewoźniak K, Zatoński M. Epidemiologia nowotworów złośliwych w Polsce. In: Zachorowalność i umieralność na nowotwory a sytuacja demograficzna Polski. Potrykowska A, Strzelecki Z, Szymborski J, Witkowski J (eds). Rządowa Rada Ludnościowa, Warsaw 2014.

5. Boyle P, Autier P, Bartelnik H, Baselga J, Boffetta P, Burn HJ, Burns HJG, Denis L, Dicato M, Diehl V, Doll R, Franceschi S, Gillis CR, Gray N, Griciute L, Hackshaw A, Kasler M, Kogevinas M, Kvinnsland S, La Vecchia C, Levi F, McVie JG, Maisonneuve P, Martin-Moreno JM, Newton Bishop J, Oleari F, Perrin P, Quinn M, Richards M, Ringborg U, Scully C, Siracka E, Storm H, Tubiana M, Tursz T, Veronesi U, Wald N, Weber W, Zaridze DG, Zatoński W, zur Hausen H. Europejski kodeks walki z rakiem 2003. Zatoński W (ed.). Centrum Onkologii - Instytut im. Marii Skłodowskiej-Curie, Warsaw 2009.

6. World Health Organization (WHO) Regional Office for Europe, Review of Social Determinants and the Health Divide in the WHO European Region. Final Report. Marmot M (Zatoński W. Współautor raportu i przewodniczący grupy roboczej "Ill health prevention and treatment"). WHO Regional Office for Europe, UCL Institute of Health Equity, Kopenhaga, Dania 2013.

7. Didkowska J, Wojciechowska U, Zatoński W. Prognozy zachorowalności i umieralności na nowotwory złośliwe w Polsce do 2025 roku. Krajowy Rejestr Nowotworów, Warsaw 2009. 
8. Hakulinen T, Dyba T. Precisin of incidence predictions based on poisson distributed observations. Stat Med 1994; 13: 1513-1523.

9. Zatoński W, Przewoźniak K. Ograniczanie zachorowalności i umieralności z powodu chorób nowotworowych. In: Zdrowie Publiczne i Polityka Ludnościowa. Vol. II. Szymborski J (ed.). Rządowa Rada Ludnościowa, Warsaw 2012; 78-89.

10. Robins G, Crabtree JE, Bailey A, Forman D. International variation in Helicobacter pylori infection and rates of esophageal cancer. Eur J Cancer 2008; 44: 726-732.

11. Zhang FF, Terry MB, Hou L, Chen J, Lissowska J, Yeager M, Zatoński W, Chanock S, Morabia A, Chow WH. Genetic polymorphisms in folate metabolism and the risk of stomach cancer. Cancer Epidemiol Biomarkers Prev 2007; 16: 115-121.

12. Zhang FF, Hou L, Terry MB, Lissowska J, Morabia A, Chen J, Yeager M, Zatoński W, Chanock S, Chow WH. Genetic polymorphisms in alcohol metabolism, alcohol intake and the risk of stomach cancer in Warsaw, Poland. Int J Cancer 2007; 121: 2060-2064.

13. Onkologia. Podręcznik dla studentów i lekarzy. Kordek R (ed). Via Medica, Gdańsk 2007; 2-114.

14. Europejski kodeks walki z rakiem. Zatoński W (ed). Centrum Onkologii - Instytut im. Marii Skłodowskiej-Curie, Warsaw 2009; 17-95.

15. Mańczuk M. Oszacowanie liczby zgonów nowotworowych wynikających z palenia tytoniu w Polsce. Centrum Onkologii - Instytut im. Marii Skłodowskiej-Curie, Warsaw 2012.

16. Wojciechowska U, Didkowska J, Zatoński W. Nowotwory złośliwe w Polsce w 2009 roku. Centrum Onkologii - Instytut im. Marii Skłodowskiej-Curie, Warsaw 2008; 13-19.

\section{Address for correspondence:}

Małgorzata Biskup MD

Department of Rehabilitation

Holycross Cancer Centre

ul. Artwińskiego 3, 25-734 Kielce, Poland

Phone: +48606 645865

E-mail: mbiskup@onet.eu 